\title{
Advantage of recombinant borrelial proteins for serodiagnosis of neuroborreliosis
}

\author{
R. KAISER and S. RAUER \\ Neurologische Klinik und Poliklinik der Albert-Ludwigs-Universität Freiburg, Germany
}

\begin{abstract}
Two enzyme immunoassay (EIA) systems were compared for their ability to detect Borrelia burgdorferi sensu lato specific IgG and IgM antibodies and to differentiate between symptomatic ( 83 patients with neuroborreliosis) and asymptomatic seropositive subjects (80 healthy controls). Antibody concentrations were determined by EIA; the antigens used were either a sonicate of $B$. burgdorferi or three recombinant borrelial proteins: the 14-kDa flagellin fragment, the outer surface protein $C(22 \mathrm{kDa})$ and the high molecular mass protein p83 $(83 \mathrm{kDa})$. In the sonicate, EIA, IgG or IgM antibodies to $B$. burgdorferi, or both, were detected in all patients with neuroborreliosis and in all controls. Pre-absorption of sera with Treponema phagedenis sonicate diminished the sensitivity of detection of borrelial specific IgG (IgG or IgM or both) antibodies in patients with neuroborreliosis from 80 to $57 \%(100$ to $82 \%)$ and in the controls from 100 to $32 \%(100$ to $37 \%)$. While being specific for $B$. burgdorferi, the recombinant EIAs proved to be significantly more sensitive than the sonicate EIA: IgG or IgM, or both antibodies against any of the recombinant antigens were detected in $92 \%$ of patients with neuroborreliosis and in $\mathbf{2 4 \%}$ of controls. The increase in sensitivity in patients with neuroborreliosis was mostly due to the higher detection rate of IgM antibodies in the recombinant EIA (77\% versus $48 \%$ in the sonicate EIA), while IgG antibodies were demonstrated with similar frequencies in both EIA systems $(57 \%$ versus $60 \%)$. It was concluded that the recombinant EIAs are superior to the sonicate EIA with preabsorption of cross-reactive antibodies in the confirmation of an acute borrelial infection and in the differentiation between symptomatic and asymptomatic infections.
\end{abstract}

\section{Introduction}

Lyme borreliosis is a multi-system disorder involving skin, joints, the heart and the central nervous system [1-4]. To differentiate diseases with similar clinical symptoms, highly sensitive and specific serological tests are needed. However, there are several basic problems associated with the evaluation of serological tests for borrelia infections. No individual test has been accepted as the reference method to demonstrate an infection with Borrelia burgdorferi sensu lato [3,511]. A gold standard would be the isolation of $B$. burgdorferi from human body fluids or tissue, but this agent is difficult to culture from patients because of its fastidious nature and because the number of organisms in body fluids appears to be small. An approximate gold standard, which has yet to be defined, should

Received 13 Feb. 1998; revised version accepted 9 April 1998.

Corresponding author: Dr R. Kaiser. include not only typical clinical symptoms of Lyme borreliosis, but also additional laboratory findings such as evidence of inflammation in the cerebrospinal fluid in patients with neuroborreliosis.

At present, serological tests for Lyme disease usually include enzyme immunoassays (EIA) and indirect immunofluorescent assays (IFA).' These tests employ whole cells or extracts of $B$. burgdorferi $[3,6,11]$. They have adequate sensitivity, but are lacking in specificity because of epitopes of $B$. burgdorferi that cross-react with other bacterial species $[5,12,13]$. The specificity of serological assays can be improved by adsorption of non-specific antibodies, but this procedure frequently reduces sensitivity $[13,14]$. Alternatively, the diagnosis of Lyme borreliosis might be established by a two-test protocol: the first step would be a sensitive but not very specific serological test, such as a whole-cell extract EIA, and the second would be a confirmatory test such as immunoblotting (Western blot) [15]. Apart from immunoblotting with whole-cell extracts of $B$. burgdorferi, EIA with 
recombinant borrelial proteins represents a suitable method to confirm a borrelial infection [16-23].

The present study investigated the significance of three recombinantly expressed borrelial proteins: first, for the detection of $B$. burgdorferi-specific IgM and IgG antibodies; second, for the differentiation between symptomatic and asymptomatic infections; and third, as confirmatory antigens in the serodiagnosis of neuroborreliosis. The outer surface protein (Osp) $\mathrm{C}$ $(22 \mathrm{kDa})$, the $14-\mathrm{kDa}$ flagellin fragment and the high molecular mass protein p83 (synonyms: p93, p94, p100) were employed as antigens.

\section{Materials and methods}

\section{Subjects}

Serum samples were obtained from 83 patients with neuroborreliosis who had been admitted to the Department of Neurology of the University of Freiburg between 1990 and 1997. Sixty-seven patients had acute neuroborreliosis (duration of symptoms $\leqslant 6$ months: lymphocytic meningoradiculitis, 56; encephalitis, 8; myelitis, 2; cerebral vasculitis, 1) and 16 had chronic neuroborreliosis (duration of symptoms $>6$ months: encephalomyelitis, 14; polyneuritis in association with acrodermatitis chronica atrophicans, 2).

Except for two patients with peripheral polyneuritis, the diagnosis of neuroborreliosis was based on lymphocytic pleocytosis, and assessment of $B$. burgdorferi-specific IgM or IgG antibodies, or both, in serum by routine serological tests as follows: (1) a titre of $>320$ in a passive haemagglutination assay with a mixture of antigens from $B$. burgdorferi sensu lato strain GeHo, B. afzelii (provided by K. Pelz, Institute of Medical Microbiology of the University of Freiburg, passage number $>25$ ) and $B$. garinii (provided by $\mathrm{B}$. Wilske, Max von Pettenkofer Institute, Munich); (2) a positive titre (IgM $>24, \operatorname{IgG}>32)$ in an IFA. Specimens were tested at the Department of Immunology in the Institute of Medical Microbiology of the University of Freiburg. Intrathecal synthesis of IgG or IgM antibodies (or both) to $B$. burgdorferi in sonicate EIA was demonstrated in 71 patients $(86 \%)$ and at follow-up examinations in $81(98 \%)$ of 83 patients. The detailed CSF data are shown in Table 1.
All patients were treated with ceftriaxone $2 g$ daily for 2 weeks (acute) or 3 weeks (chronic).

\section{Controls}

In 1995, an epidemiological study was conducted to evaluate the frequency of $B$. burgdorferi seropositive subjects living in an area endemic for this infection [24]. Patients and their relatives who went to an ambulatory practice were questioned for symptoms compatible with Lyme borreliosis and asked to provide serum samples. Of all subjects who were seropositive $(158 / 393 ; 40 \%), 80$ persons did not recall any symptoms indicating a previous infection with $B$. burgdorferi. These individuals were either healthy or had diseases of other aetiology (diabetes mellitus, surgery).

\section{Bacterial strains and antigens}

B. burgdorferi sensu lato strain GeHo isolated from a patient with erythema migrans was used in this study [25]. Spirochaetes were grown in modified Kelly's medium according to standard techniques, centrifuged at $10000 \mathrm{rpm}$ for $30 \mathrm{~min}$, and washed three times in phosphate-buffered saline (PBS). Spirochaetes were sonicated for $5 \mathrm{~min}$ and dissolved in $6 \mathrm{M}$ urea to a final concentration of $2 \mathrm{mg} / \mathrm{ml}$. DNA of strain GeHo was used for cloning of $\mathrm{OspC}, \mathrm{p} 83$ and the $14-\mathrm{kDa}$ flagellin fragment. The expression and purification of these proteins was performed according to standard methods as described previously $[21,26]$.

\section{Enzyme immunoassay}

Microtitration plates were coated with $100 \mu \mathrm{l}$ of $B$. burgdorferi sensu stricto strain GeHo sonicate $(20 \mu \mathrm{g} / \mathrm{ml})$ in PBS or with individual preparations of recombinant proteins ( $14 \mathrm{kDa}, 22 \mathrm{kDa}, 83 \mathrm{kDa}: 0.5 \mu \mathrm{g} /$ $\mathrm{ml})$ in coating buffer $\left(15 \mathrm{mM} \mathrm{Na} \mathrm{CO}_{3}, 35 \mathrm{mM}\right.$ $\mathrm{NaHCO}_{3}, \mathrm{pH}$ 9.5) and incubated overnight at $4^{\circ} \mathrm{C}$. The optimal antigen concentration for coating of EIA plates had been determined in preliminary experiments by checkerboard titration of two-fold dilutions of antigen and high-titre sera. Unspecified protein binding was blocked with $100 \mu \mathrm{l}$ of dilution buffer (BSA 1\%, Tween-20 $0.1 \%$ in PBS) for $1 \mathrm{~h}$. Samples to be tested for IgG (IgM) antibodies were diluted 10000-(2000-)

Table 1. Cerebrospinal fluid findings in patients with acute and chronic neuroborreliosis

\begin{tabular}{|c|c|c|c|c|c|}
\hline \multirow[b]{2}{*}{ Assay } & \multirow[b]{2}{*}{ Normal } & \multicolumn{2}{|c|}{$\begin{array}{l}\text { Acute neuroborreliosis } \\
\qquad(\mathrm{n}=67)\end{array}$} & \multicolumn{2}{|c|}{$\begin{array}{l}\text { Chronic neuroborreliosis } \\
\qquad(\mathrm{n}=16)\end{array}$} \\
\hline & & $\begin{array}{c}\text { Number of patients with } \\
\text { abnormal values }\end{array}$ & Median (range) & $\begin{array}{l}\text { Number of patients with } \\
\text { abnormal values }\end{array}$ & Median (range) \\
\hline Leucocytes/ $\mu \mathrm{l}$ & $<5$ & 67 & $241 \quad(7-600)$ & 14 & $60(10-135)$ \\
\hline Q-albumin $\left(\times 10^{-3}\right)$ & $<7.5$ & 47 & $20(4-58)$ & 14 & $35(10-70)$ \\
\hline Oligoclonal IgG bands & None & 54 & & 14 & \\
\hline IgG synthesis (\%) & 0 & 42 & $20(10-50)$ & 14 & $40 \quad(5-75)$ \\
\hline IgM synthesis (\%) & 0 & 50 & $50(10-95)$ & 7 & $15(10-80)$ \\
\hline IgA synthesis (\%) & 0 & 19 & $10(5-50)$ & 8 & $30(15-80)$ \\
\hline
\end{tabular}


and 1000-(200-)fold. For pre-absorption of cross-reactive IgG antibodies, $100 \mu \mathrm{l}$ of 100 -fold pre-diluted sera were incubated with $100 \mu \mathrm{l}$ of Treponema phagedenis $1.0 \mathrm{mg} / \mathrm{ml}$. After incubation at $37^{\circ} \mathrm{C}$ for $1 \mathrm{~h}$, samples were pelleted by centrifugation at $13000 \mathrm{rpm}$ for $20 \mathrm{~min}$. The supernate was used for further dilution steps. Control samples were treated in the same way. Antibodies to $B$. burgdorferi were tested on the same plate with and without pre-absorption with $T$. phagedenis. Before performing the IgM antibody assay, total IgG was immunoprecipitated by the method of Müller et al. [27]. Control samples were treated in the same way. Specimens were incubated for $2 \mathrm{~h}$. After washing, $100 \mu \mathrm{l}$ of peroxidase-conjugated goat anti-human IgG ( 1 in 10000 , Dianova, Hamburg, Germany) or antihuman IgM antibodies ( 1 in 4000, Dianova) were added. After $1.5 \mathrm{~h}$ at room temperature in a dark chamber, the plates were washed and $100 \mu \mathrm{l}$ of $o$ phenylenediamine in citrate buffer $(\mathrm{pH} 5)$ containing $\mathrm{H}_{2} \mathrm{O}_{2} \quad 0.04 \%$ were added to each well. The enzymic reaction was stopped after $20 \mathrm{~min}$ by the addition of $30 \mu \mathrm{l}$ of $2.5 \mathrm{~N} \mathrm{H}_{2} \mathrm{SO}_{4}$. The optical densities at $492 \mathrm{~nm}$ $\left(\mathrm{OD}_{492}\right)$ were measured with a Titertek Multiscan reader. The cut-off value was defined as the mean $\mathrm{OD}_{492}$ of 80 negative controls (healthy students with no history of Lyme borreliosis and negative findings in Western blotting) plus two SD. Samples were tested in duplicate and the mean value was calculated. Negative controls were included on every plate. The cut-off values are shown in Table 2 .

\section{Statistical analysis}

The frequency of positive results in both groups was examined by the $\chi^{2}$ test, with SPSS $/ \mathrm{PC}^{+}$software. A $\mathrm{p}$ value $<0.05$ was considered significant.

\section{Results}

\section{Sonicate EIA and absorption of cross-reactive $\operatorname{Ig} G$ antibodies}

The sonicate EIA showed that $67(80 \%)$ of the 83 patients with neuroborreliosis had IgG antibodies and $40(48 \%)$ had IgM antibodies to $B$. burgdorferi in serum; all patients displayed either IgG or IgM antibodies, or both. After pre-absorption with $T$. phagedenis, $47(70 \%)$ of 67 samples were still positive for IgG-antibodies and $68(82 \%)$ of 83 samples were still positive for IgG or IgM antibodies, or both. Of 20 patients who became negative after absorption of crossreactive antibodies, recent infection with $B$. burgdorferi was demonstrated by intrathecal synthesis of borrelialspecific IgG or IgM antibodies (or both) in 15, and by increasing titres of specific $\operatorname{IgM}$ antibodies in five.

IgM antibodies to $B$. burgdorferi were detected more frequently in patients with acute neuroborreliosis $(38 / 67 ; 57 \%)$ than in those with chronic neuroborreliosis $(2 / 16 ; 12 \%)$. In contrast, IgG antibodies were demonstrated in all patients with chronic neuroborreliosis, but in only $31(46 \%)$ of 67 patients with acute neuroborreliosis.

In seropositive healthy subjects, IgG antibodies were present in all and IgM antibodies in $8(10 \%)$ of 80 samples. After pre-absorption with $T$. phagedenis, only $26(32 \%)$ of 80 samples were still positive. The detailed data are shown in Table 3.

\section{Recombinant proteins}

The frequency of IgG and IgM antibodies to individual recombinant borrelial antigens is shown in Tables 4-6.

Table 2. Cut-off values in EIA

\begin{tabular}{lcccc}
\hline & \multicolumn{4}{c}{$\mathrm{OD}_{492}$ cut-off value } \\
\cline { 2 - 5 } & $\begin{array}{c}\text { B. burgdorferi } \\
\text { sonicate }\end{array}$ & $14 \mathrm{kDa}$ & $22 \mathrm{kDa}$ & $83 \mathrm{kDa}$ \\
\hline Igmunoglobulin & 0.4 & 0.15 & 0.17 & 0.10 \\
IgG & 0.3 & 0.31 & 0.34 & 0.26 \\
IgG (after pre-absorption) & 0.1 & $\ldots$ & $\ldots$ & $\ldots$ \\
\hline
\end{tabular}

Table 3. Prevalence of IgG and IgM antibodies to $B$. burgdorferi in sonicate EIA

\begin{tabular}{lccc}
\hline & \multicolumn{2}{c}{ Number (\%) of positive results } & \\
\cline { 2 - 3 } & $\begin{array}{c}\text { Neuroborreliosis: } \\
(\mathrm{n}=83)\end{array}$ & $\begin{array}{c}\text { Controls: } \\
(\mathrm{n}=80)\end{array}$ & $\mathrm{p}$ value \\
\hline Immunoglobulin & $67(81)$ & $80(100)$ & \\
IgG & $47(57)$ & $26(32)$ & 0.002 \\
IgG and absorption & $40(48)$ & $8(10)$ & 0.0001 \\
IgM & $83(100)$ & $80(100)$ & $\mathrm{NS}$ \\
IgM or IgG or both & $68(82)$ & $30(37)$ & 0.0001 \\
\hline IgM or IgG or both and absorption & & &
\end{tabular}


In patients with neuroborreliosis, employment of the three recombinant borrelial proteins increased the sensitivity of detection of specific IgM antibodies from $48 \%$ in sonicate EIA to $77 \%$ in recombinant EIA, while in seropositive controls the frequency of $\operatorname{IgM}$ antibodies fell from $10 \%$ to $7.5 \%$ (Table 4 ).

In patients with neuroborreliosis, the sensitivity of detection of specific IgG antibodies was similar in the recombinant $(60 \%)$ and in the sonicate $(57 \%)$ EIA method, if the latter was performed after pre-absorption of cross-reactive antibodies. Of 40 patients with neuroborreliosis that were $\operatorname{IgM}$ positive in the sonicate EIA, $31(77 \%)$ were also positive in the recombinant EIA. On the other hand, a further 33 patients with neuroborreliosis were positive in the recombinant EIA, but negative in the sonicate EIA. The frequency of IgM antibody reactions in these 33 patients did not differ significantly between the various proteins $(14 \mathrm{kDa}$, $\mathrm{n}=18 ; 22 \mathrm{kDa}, \mathrm{n}=15 ; 83 \mathrm{kDa}, \mathrm{n}=19$ ).
In seropositive controls without clinical symptoms, the sensitivity of detection of IgG antibodies fell from $32 \%$ in the sonicate EIA (after pre-absorption of cross-reactive antibodies) to $18 \%$ in the recombinant EIA $(\mathrm{p}<0.05)($ Table 5).

Evaluation of the prevalence of IgM or IgG antibodies, or both, to any of the three recombinant borrelial proteins revealed a sensitivity of $92 \%$ in patients with neuroborreliosis, but only $24 \%$ in asymptomatic controls $(p<0.0001)$ (Table 6).

Differences between patients with acute and chronic neuroborreliosis concerning the frequency of antibody reactions to any recombinant protein were detected for only two combinations: IgG antibodies to the $83-\mathrm{kDa}$ protein were detected more frequently in patients with chronic neuroborreliosis $(56 \%)$ than in those with acute neuroborreliosis $(30 \% ; \mathrm{p}=0.046)$, and $\operatorname{IgM}$ antibodies to the $14-\mathrm{kDa}$ protein were more frequent in patients

Table 4. Prevalence of $\operatorname{IgM}$ antibodies to individual recombinant borrelial proteins

\begin{tabular}{lccc}
\hline \multicolumn{3}{c}{ Number $(\%)$ of positive results } & \\
\cline { 2 - 4 } Proteins & Neuroborreliosis: $(\mathrm{n}=83)$ & Controls: $(\mathrm{n}=80)$ & p value \\
\hline $14 \mathrm{kDa}$ & $41(49)$ & $4(5)$ & $<0.0001$ \\
$22 \mathrm{kDa}$ & $39(47)$ & 0 & $<0.0001$ \\
$83 \mathrm{kDa}$ & $32(39)$ & $4(5)$ & $<0.0001$ \\
$14 / 22 \mathrm{kDa}$ & $58(70)$ & $4(5)$ & $<0.0001$ \\
$14 / 83 \mathrm{kDa}$ & $55(66)$ & $6(7)$ & $<0.0001$ \\
$22 / 83 \mathrm{kDa}$ & $50(60)$ & $4(5)$ & $<0.0001$ \\
$14 / 22 / 83 \mathrm{kDa}$ & $64(77)$ & $6(7)$ & 0.0001 \\
\hline
\end{tabular}

Table 5. Prevalence of IgG antibodies to individual recombinant borrelial proteins

\begin{tabular}{|c|c|c|c|}
\hline \multirow[b]{2}{*}{ Proteins } & \multicolumn{2}{|c|}{ Number $(\%)$ of positive results } & \multirow[b]{2}{*}{$\mathrm{p}$ value } \\
\hline & Neuroborreliosis: $(n=83)$ & Controls: $(n=80)$ & \\
\hline $14 \mathrm{kDa}$ & $28(34)$ & $6 \quad(7)$ & $<0.0001$ \\
\hline $22 \mathrm{kDa}$ & $9(11)$ & 1 (1) & 0.008 \\
\hline $83 \mathrm{kDa}$ & $29(35)$ & $12(15)$ & 0.003 \\
\hline $14 / 22 \mathrm{kDa}$ & $33(40)$ & $6(7)$ & $<0.0001$ \\
\hline $14 / 83 \mathrm{kDa}$ & $45(54)$ & $14(18)$ & $<0.0001$ \\
\hline $22 / 83 \mathrm{kDa}$ & $36(43)$ & $12(15)$ & $<0.0001$ \\
\hline $14 / 22 / 83 \mathrm{kDa}$ & $50(60)$ & $14(18)$ & $<0.0001$ \\
\hline
\end{tabular}

Table 6. Prevalence of $\operatorname{IgM} / \mathrm{G}$ antibodies to individual recombinant borrelial proteins

\begin{tabular}{lccc}
\hline \multicolumn{4}{c}{ Number $(\%)$ of positive results } \\
\cline { 2 - 3 } Proteins & Neuroborreliosis: $(\mathrm{n}=83)$ & Controls: $(\mathrm{n}=80)$ & p value \\
\hline $14 \mathrm{kDa}$ & $52(63)$ & $10(12)$ & $<0.0001$ \\
$22 \mathrm{kDa}$ & $40(48)$ & 1 & $(1)$ \\
$83 \mathrm{kDa}$ & $49(59)$ & $16(20)$ & $<0.0001$ \\
$14 / 22 \mathrm{kDa}$ & $64(77)$ & $10(12)$ & $<0.0001$ \\
$14 / 83 \mathrm{kDa}$ & $70(84)$ & $19(24)$ & $<0.0001$ \\
$22 / 83 \mathrm{kDa}$ & $64(77)$ & $16(20)$ & $<0.0001$ \\
$14 / 22 / 83 \mathrm{kDa}$ & $76(92)$ & $19(24)$ & $<0.0001$ \\
\hline
\end{tabular}


with acute neuroborreliosis, (53\%) than in chronic neuroborreliosis $(31 \% ; \mathrm{p}=0.1$, not significant).

\section{Discussion}

The present study investigated the significance of recombinantly expressed borrelial proteins for serodiagnosis of neuroborreliosis. As no individual test has been accepted as the reference method for demonstration of an infection with $B$. burgdorferi, the most critical aspect in such investigations is designation of a gold standard [3,5-11]. The 'approximate gold standard' in the present study was a group of patients who presented with typical clinical symptoms of neuroborreliosis, inflammatory findings in the cerebrospinal fluid and an intrathecal synthesis of borreliaspecific antibodies.

The main finding of this study was an improved sensitivity of the recombinant EIAs over the sonicate EIA to detect borrelia-specific IgM antibodies in patients with neuroborreliosis. This finding might be explained by higher concentrations of IgM-relevant epitopes in the wells of the recombinant EIAs when compared with the variety of different antigens in a whole-cell sonicate EIA.

The frequent finding of IgM antibodies to the OspC and the 14-kDa flagellin fragment in this study is in line with the findings reported by Wilske et al. who estimated sensitivities of $43 \%$ for $\operatorname{IgM}$ antibodies against $\mathrm{OspC}$ in a recombinant immunoblot and of $46 \%$ for IgM antibodies to the $14-\mathrm{kDa}$ flagellin fragment [28]. Gerber et al. found sensitivities of $48 \%$ for a recombinant OspC-IgM EIA and of only $28 \%$ for a whole-cell-IgM EIA in 82 patients with erythema migrans [17]. The high incidence of IgM antibodies to the $83-\mathrm{kDa}$ antigen has not been described previously in neuroborreliosis. Wilske et al. reported sensitivities of a recombinant immunoblot for detection of $\operatorname{IgM}$ antibodies to the p100 antigen (the $\mathrm{p} 83$ homologue in their study) in neuroborreliosis to be $7 \%$ and $12 \%$ [23]. A similar result was reported by Rauer et $a l$., with $9 \%$ sensitivity achieved by a recombinant p83-IgM EIA in neuroborreliosis [22]. The present study confirmed the positive results of the p83-IgM EIA by recombinant and native immunoblot (data not shown). Differences in case definition and the time of collection of sera with respect to clinical course might be the most appropriate reasons for the discrepancies revealed. As shown in a previous study, the choice of species (e.g., B. burgdorferi sensu stricto versus $B$. afzelii) probably does not influence the sensitivity of the assay [22]. Both strains show a high degree of sequence homology $(89 \%)$ of the antigens $[29,30]$.

Borrelia-specific IgG antibodies may persist for many years in the sera of patients previously infected with
B. burgdorferi, while IgM antibodies appear mostly during early infection and thereafter decline gradually. In patients with atypical clinical symptoms, it is difficult to differentiate between an 'anamnestic IgG antibody titre' and a relevant titre related to active disease. In this situation, increased sensitivity of the recombinant EIA in the detection of IgM antibodies might be of advantage in differentiating between active and recent disease.

Another finding in the present study was the advantage of the recombinant EIAs over the sonicate EIA in detecting $B$. burgdorferi-specific antibodies. In sonicate EIA, IgG antibodies specific for this agent can be demonstrated only after absorption of samples with Reiter spirochaetes. However, this procedure is time-consuming and expensive. Antibody testing by recombinant EIAs requires no pre-absorption of crossreactive antibodies and in this study was even a little more sensitive than testing by sonicate EIA $[18,22,31]$.

In many cases, screening for antibodies to $B$. burgdorferi is requested for patients with ambiguous symptoms. If both the screening and confirmatory assays are positive, the clinician has to consider a borrelial infection as a possible cause of the patient's complaints. However, if the confirmatory assay is negative, other reasons for the symptoms are more likely. The higher sensitivity of the recombinant EIAs for the detection of borrelial antibodies in patients with neuroborreliosis and the lower detection rate of this assay for borrelial antibodies in healthy subjects, support its use in patients with uncertain clinical symptoms because of its increased predictive value.

In conclusion, the overall sensitivity of the three recombinant antigens for detection of $\operatorname{IgM}$ antibodies was significantly better when compared with the sonicate EIA. Sensitivity of the recombinant EIAs decreases if any of the three antigens is excluded. High specificity of the recombinant antigens has been demonstrated in earlier studies [18, 22, 32, 33]. Consequently, when neuroborreliosis is suspected, the use of the recombinant EIAs will be helpful in confirming the suspected diagnosis.

This work was supported by the Bundesministerium für Bildung und Forschung (01KI 9504/9). We are indebted to Christiane Rasiah (ravo-Diagnostika $\mathrm{GmbH}$, Freiburg, Germany) for providing the recombinant $14-\mathrm{kDa}$ flagellin fragment.

\section{References}

1. Finkel MJ, Halperin JJ. Nervous system Lyme borreliosis revisited. Arch Neurol 1992; 49: 102-107.

2. Garcia-Monco JC, Benach JL. Lyme neuroborreliosis. Ann Neurol 1995; 37: 691-702.

3. Halperin JJ, Logigian EL, Finkel MF, Pearl RA. Practice parameters for the diagnosis of patients with nervous system Lyme borreliosis (Lyme disease). Neurology 1996; 46: 619-627.

4. Hansen K, Lebech A-M. The clinical and epidemiological 
profile of Lyme neuroborreliosis in Denmark 1985-1990. A prospective study of 187 patients with Borrelia burgdorferi specific intrathecal antibody production. Brain 1992; 115: 399-423.

5. Barbour AG. Laboratory aspects of Lyme borreliosis. Clin Microbiol Rev 1988; 1: 399-414.

6. Hansen K. Laboratory diagnostic methods in Lyme borreliosis. Clin Dermatol 1993; 11: 407-414.

7. Pachner AR, Delaney E. The polymerase chain reaction in the diagnosis of Lyme neuroborreliosis. Ann Neurol 1993; 34: 544-550.

8. Schmidt BL. PCR in laboratory diagnosis of human Borrelia burgdorferi infections. Clin Microbiol Rev 1997; 10: 185-201.

9. Steere AC, Berardi VP, Weeks KE, Logigian EL, Ackermann R. Evaluation of the intrathecal antibody response to Borrelia burgdorferi as a diagnostic test for Lyme neuroborreliosis. J Infect Dis 1990; 161: 1203-1209.

10. Stiernstedt G, Dattwyler R, Duray PH et al. Diagnostic tests in Lyme borreliosis. Scand J Infect Dis Suppl 1991; 77: 136-142.

11. Tilton RC. Laboratory aids for the diagnosis of Borrelia burgdorferi infection. J Spirochetal Tick-Borne Dis 1994; 1: $18-23$.

12. Bruckbauer HR, Preac-Mursic V, Fuchs R, Wilske B. Crossreactive proteins of Borrelia burgdorferi. Eur J Clin Microbiol Infect Dis 1992; 11: 224-232.

13. Kaiser $R$. Intrathecal immune response in neuroborreliosis: importance of cross-reactive antibodies. Int $J$ Med Microbiol Virol Parasitol Infect Dis 1995; 282: 303-314.

14. Magnarelli LA, Anderson JF, Johnson RC. Cross-reactivity in serological tests for Lyme disease and other spirochetal infections. $J$ Infect Dis 1987; 156: 183-188.

15. CDC/DVBID. Standardisation of Lyme disease serodiagnosis: working groups meet to chart progress. $C D C$ 1994; 5: 1-3.

16. Fikrig E, Huguenel ED, Berland R, Rahn DW, Hardin JA Flavell RA. Serologic diagnosis of Lyme disease using recombinant outer surface proteins $\mathrm{A}$ and $\mathrm{B}$ and flagellin. $J$ Infect Dis 1992; 165: 1127-1132.

17. Gerber MA, Shapiro ED, Bell GL, Sampieri A, Padula SJ. Recombinant outer surface protein C ELISA for the diagnosis of early Lyme disease. $J$ Infect Dis 1995; 171: 724-727.

18. Kaiser R, Rasiah C, Gassmann G, Vogt A, Lücking $\mathrm{CH}$ Intrathecal antibody synthesis in Lyme neuroborreliosis: use of recombinant $\mathrm{p} 41$ and a $14-\mathrm{kDa}$ flagellin fragment in ELISA. $J$ Med Microbiol 1993; 39: 290-297.

19. Padula SJ, Sampieri A, Dias F, Szczepanski A, Ryan RW. Molecular characterization and expression of p23 (OspC) from a North American strain of Borrelia burgdorferi. Infect Immun 1993; 61: 5097-5105.

20. Perng GC, LeFebvre RB, Johnson RC. Further characterization of a potent immunogen and the chromosomal gene encoding it in the Lyme disease agent, Borrelia burgdorferi. Infect Immun 1991; 59: 2070-2074.
21. Rasiah C, Schiltz E, Reichert J, Vogt A. Purification and characterization of a tryptic peptide of Borrelia burgdorferi flagellin, which reduces cross-reactivity in immunoblots and ELISA. $J$ Gen Microbiol 1992; 138: 147-154.

22. Rauer S, Kayser M, Neubert U, Rasiah C, Vogt A. Establishment of enzyme-linked immunosorbent assay using purified recombinant 83-kilodalton antigen of Borrelia burgdorferi sensu stricto and Borrelia afzelii for serodiagnosis of Lyme disease. J Clin Microbiol 1995; 33: 2596-2600.

23. Wilske B, Fingerle V, Herzer $\mathrm{P}$ et al. Recombinant immunoblot in the serodiagnosis of Lyme borreliosis. Comparison with indirect immunofluorescence and enzyme-linked immunosorbent assay. Med Microbiol Immunol 1993; 182: 255-270.

24. Kaiser R, Kern A, Kampa D, Neumann-Haefelin D. Prevalence of antibodies to Borrelia burgdorferi and tick-borne encephalitis virus in an endemic region in southern Germany. Zentralbl Bakteriol 1996; 286: 534-541.

25. Adam T, Gassmann GS, Rasiah C, Gobel UB. Phenotypic and genotypic analysis of Borrelia burgdorferi isolates from various sources. Infect Immun 1991; 59: 2579-2585.

26. Rasiah C, Rauer S, Gassmann GS, Vogt A. Use of a hybrid protein consisting of the variable region of the Borrelia burgdorferi flagellin and part of the $83-\mathrm{kDa}$ protein as antigen for serodiagnosis of Lyme disease. J Clin Microbiol 1994; 32: 1011-1017.

27. Müller F, Moskophidis M, Borkhard HL. Detection of immunoglobulin $\mathrm{M}$ antibodies to Treponema pallidum in a modified immunosorbent assay. Eur J Clin Microbiol 1987; 6: 35-39.

28. Wilske B, Fingerle V, Preac-Mursic V et al. Immunoblot using recombinant antigens derived from different genospecies of Borrelia burgdorferi sensu lato. Med Microbiol Immunol 1994; 183: $43-59$.

29. Jauris-Heipke S, Fuchs R, Hofmann A et al. Molecular characterization of the p100 gene of Borrelia burgdorferi strain PKo. FEMS Microbiol Lett 1993; 114: 235-241.

30. Rossler D, Eiffert H, Jauris-Heipke S et al. Molecular and immunological characterization of the p83/100 protein of various Borrelia burgdorferi sensu lato strains. Med Microbiol Immunol 1995; 184: 23-32.

31. Mathiesen MJ, Hansen, K, Axelsen N, Halkier-Sorensen L, Theisen M. Analysis of the human antibody response to outer surface protein C (OspC) of Borrelia burgdorferi sensu stricto, B. garinii, and B. afzelii. Med Microbiol Immunol 1996; 185: $121-129$.

32. Magnarelli LA, Fikrig E, Padula SJ, Anderson JF, Flavell RA Use of recombinant antigens of Borrelia burgdorferi in serologic tests for diagnosis of lyme borreliosis. $J$ Clin Microbiol 1996; 34: 237-240.

33. Wilske $\mathrm{B}$, Busch $\mathrm{U}$, Fingerle $\mathrm{V}$ et al. Immunological and molecular variability of OspA and OspC. Implications for Borrelia vaccine development. Infection 1996; 24: 208-212. 